\title{
EXAMINATION OF FORM NOT SUBSTANCE: RETHINKING THE PATENT EXAMINATION PROCESS IN NIGERIA
}

\author{
Kasim Musa Waziri' and Gwom Solomon Gwom²
}

\begin{abstract}
$\mathrm{n}$ an age where knowledge assets play significant roles in the economic development of nations, the patent system has become one of the essential drivers of technological and economic advancement. Thus, the essence of examining inventions is to ensure good quality of patents granted by a patent office and to ensure that such patent applications satisfy the novelty, inventive step, and industrial application criteria. It is standard practice in most countries that patent applications by patentees go through examination processes before they are granted patents. Local patent rules usually guide such examination processes. The Nigerian patent system is not an exception to such practice. However, it suffices to submit only necessary documents for inspection by officials of the Nigerian Patent Registry before a patent is granted. This process of registering patents in Nigeria, which is the depository process of examination, is not thorough compared to the substantive method of examination. The substantive procedure is lacking in the Nigerian patent system. The need for a substantive process of examination in Nigeria is what this article discusses. The article recommends a mix of both the depository and the substantive process of examination in Nigeria, as practised in some countries to issue quality patents that would aid technological and economic growth in the country. The article also concludes that much more needs to be done by the government and policymakers in Nigeria in terms of funds, human resources, and other things to ensure the institution and sustenance of a substantive method of examination of patent applications.
\end{abstract}

1 Department of Public Law, Faculty of Law, University of Abuja, FCT

2 Department of Public Law, Faculty of Law, University of Abuja, FCT 


\section{Introduction}

The term "patent" is generally defined in the dictionary as "an official right to be the only person to make, use, or sell a product or an invention; a document that proves this." "It also means "an official document showing a person has the exclusive right to make and sell an invention,"4or "the grant of an exclusive right to exploit an invention." In many countries, a patent is usually granted if the patent application meets certain requirements. A substantive examination is also usually carried out to determine whether the invention meets statutory patentability standards of novelty, inventive step, and industrial application or non-obviousness. ${ }^{6}$ The notion of examination of patents began with the formalisation of the patent granting process in $1836 .{ }^{7}$ This development paved the way for patent examination and patent litigations, as known today. ${ }^{8}$ It is vital to say that the type of examination process chosen in the country may depend on economic, social, and geographical factors. There is also no denying that countries are free to choose their patent examination process. However, for there to be a grant of a quality patent, the substantive examination process is a good option. There is no gainsaying that the patent market and economic development of a country is determined by the quality of the patents that the country issues. The subject of examination of patent applications is rarely discussed within academic spheres. However, it is not only an integral part of patent protection, but it is also indispensable. The patent system revolves around patent examination. Some developing countries have harnessed their patent examination systems to their advantage. A country like Malaysia, for example, has within five years of proper planning, developed its patent examination system and addressed its national scientific and technological abilities. During the Sixth Malaysia Plan (19911995), the goals set for science and technology were to obtain a continuous scientific and technological development in Malaysia by providing necessary infrastructure that included incentives and support services for science and technology. ${ }^{9}$ Emphasis was

\footnotetext{
3 AS Hornby and AP Cowie, Oxford Advanced Learner's Dictionary of Current English (7th edn, Oxford Univ Pr 2005) 842.

4 PH Collin, Dictionary of Law, Bloomsbury Reference Book, 2004: Dictionary of Law (Bukupedia 2004) 216.

5 Elizabeth A Martin, A Dictionary of Law (5th edn, Oxford University Press 2009) 358.

6 Some countries like Luxembourg and South Africa confer patents without such a substantive examination or without assessing inventive step, like Switzerland and France. See Carlos M Correa, 'Patent Examination and Legal Fictions: How Rights Are Created on Feet of Clay' in Peter Drahos, Gustavo Ghidini and Hanns Ullrich, Kritika: Essays on Intellectual Property (Edward Elgar Publishing 2015).

7 Rochelle Cooper Dreyfuss and Justine Pila, The Oxford Handbook of Intellectual Property Law (Oxford University Press 2018) 252.

8 ibid.

9 VGR Chandran Govindaraju and Chan-Yuan Wong, 'Patenting Activities by Developing Countries: The
} 
made to ensure that public R\&D programs became more market-oriented by exploiting the commercialisation of research and technology. ${ }^{10} \mathrm{Also}$, the private sector was expected to complement the government in expanding the R\&D and science and technology by using appropriate technology assimilation, diffusion, and application. ${ }^{11}$ This stride also extended from 1995 to $2000 .{ }^{12}$

The Nigerian patent system was inherited from the British, and patents are granted under the Patents and Designs Act of $1972 .^{13}$ This legislation is still the existing legislation on issuing patents in Nigeria. ${ }^{14}$ Currently, the Act legislates on both patent and design matters with a statutory framework of eleven sections each for both subjects. ${ }^{15}$ Since its enactment, the Nigerian patent legislation has not undergone any significant reforms. It has been the unanimous agitation by scholars, researchers and policymakers that there is the need for reforms of the Nigerian patent legislation which should include its patent examination process, which does not have a substantive procedure. ${ }^{16}$ Patent

Case of Malaysia' (2011) 33 World Patent Information 51, 10.particularly due to foreign firms' participation in the Malaysian economy. As such, any shock to the economic activities of foreign firms will deter patenting trends. This also indicates that the current local indigenous innovative capabilities are still weak and require better policy intervention to accelerate the inventive capabilities of Malaysia.","containertitle":"World Patent Information","DOl":"10.1016/j.wpi.2010.01.001","ISSN":"0172-2190","issue":"1","jou rnalAbbreviation":"World Patent Information","page":"51-57","source":"ScienceDirect","title":"Patenting Activities by Developing Countries: The Case of Malaysia","title-short":"Patenting activities by developing

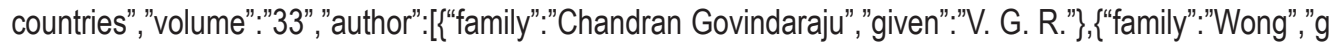
iven":"Chan-Yuan"\}],"issued":\{“date-parts":[“2011",3,1]]\}\},"locator":"10","label":"page"\}],"schema":"https:// github.com/citation-style-language/schema/raw/master/csl-citation.json"\}

$10 \mathrm{ibid}$

11 ibid

12 ibid

13 Now Cap P2, Laws of the Federation of Nigeria, 2004.(The acronym PDA shall henceforth be used to denote the Patents and Designs Act). The 2004 Act is not any different in content from the Patents and Designs Act of 1970. Cap 344 of Laws of the Federation of Nigeria, 1990.

14 s 315 of the 1999 Constitution of Nigeria makes provision for existing laws. It states that (1) Subject to the provisions of this Constitution, an existing law shall have effect with such modifications as may be necessary to bring it into conformity with the provisions of this Constitution and shall be deemed to be:

(a) an Act of the National Assembly to the extent that it is a law with respect to any matter on which the National Assembly is empowered by this Constitution to make laws; and

(b) a Law made by a House of Assembly to the extent that it is a law with respect to any matter on which a House of Assembly is empowered by this Constitution to make laws.

15 ss 1 to 11 deal with patents, while ss 12 to 22 deal with designs.

16 Observations of this nature have been raised in books, workshops and conferences respectively. See Abdulai Taiwo and Co, 'Requirements and Procedure for Patent Registration in Nigeria' (Lexicology, 6 February 2019) <https://www.lexology.com/library/detail.aspx?g=f0321f8b-0da4-4480b424-ca31ca894726> accessed 6 October 2020; George Sipa-Adjah Yankey, International Patents and 
legislation and practice remain archaic and in need of reforms. Although there are strong agitations by experts for reforms of the country's legislation and entire patent system, ${ }^{17}$ there is still no introduction of legislative or policy changes to tighten the application of the patentability requirements, introduce a rigorous examination, and reduce the proliferation of foreign patents. Thus, the focus of discussions in this article is the examination process of patents in Nigeria. There is a need for an examination process that is either solely substantive in nature or a mix of both substantive or non-substantive. The article analyses the patent examination process in Nigeria. Discussions are also bothered on patent administration reforms, which are necessary to undertake in Nigeria to have a good patent examination process.

\section{The Grant of Patents in Nigeria}

Process and product patents are registered in Nigeria to ensure that an inventor can exploit an invention exclusively and commercially. ${ }^{18}$ The rights to a granted patent are usually vested in the first person to file and register the patent. ${ }^{19}$ According to section 3 of the PDA:

(1) Every patent application-- (a) shall be made to the Registrar and shall contain-

(i) the applicant's full name and address and, if that address is outside Nigeria, an address for service in Nigeria;

(ii) a description of the relevant invention with any appropriate plans and drawings; (iii) a claim or claims; and

(iv) such other matter as may be prescribed; and (b) shall be accompanied by-

(i) the prescribed fees;

Technology Transfer to Less Developed Countries: The Case of Ghana and Nigeria (Avebury 1987) 219222; Amaka Vanni, Patent Games in the Global South: Pharmaceutical Patent Law-Making in Brazil, India and Nigeria (Bloomsbury Publishing 2020) 169. \{lli\{\}International Patents and Technology Transfer to Less Developed Countries: The Case of Ghana and Nigeria\} (Avebury 1987

17 Femi Olubanwo and Oluwatoba Oguntuase, 'Strengthening Intellectual Property Rights and Protection In Nigeria' (Mondaq, 11 March 2019) <https://www.mondaq.com/nigeria/trademark/788714/ strengthening-intellectual-property-rights-and-protection-in-nigeria> accessed 27 May 2020.

18 s 3(3).

19 s 2(1). 
(ii) where appropriate, a declaration signed by the true inventor requesting that he be mentioned as such in the patent and giving his name and address; and

(iii) if the application is made by an agent, a signed power of attorney (so however that, notwithstanding any rule of law, legalisation or certification of the signature of the power of attorney shall be unnecessary).

(2) The description referred to in subsection (I) (a) (ii) of this section shall disclose the relevant invention in a manner sufficiently clear and complete for the invention to be put into effect by a person skilled in the art or field of knowledge to which the invention relates; and the claim or claims referred to in subsection (1) (a) (iii) of this section shall define the protection sought and shall not go beyond the limits of the said description.

In order to determine newness, section 1(2) of the PDA states that "an invention is new if it does not form part of the state of the art." Section 1(3) further determines "pror art" to mean:

the art or field of knowledge to which an invention relates and "the state of the art" means everything concerning that art or field of knowledge which has been made available to the public anywhere and at any time whatever (by means of a written or oral description, by use or in any other way) before the date of the filing of the patent application relating to the invention or the foreign priority date validly claimed in respect thereof, so however that an invention shall not be deemed to have been made available to the public merely by reason of the fact that, within the period of six months preceding the filing of a patent application in respect of the invention, the inventor or his successor in title has exhibited it in an official or officially recognised international exhibition.

The examination process in the grant of patents is usually aimed at ensuring the quality of an invention by making sure that the invention does not form part of the prior art. The result is good quality patents, a potential for a rich patent market and also good investor confidence 


\section{Analysing Patent Examination in Nigeria}

One of the important tasks of a patent office is to decide whether a patent shall be granted, or an application shall be refused, based on the procedures and patentability requirements under the applicable national law. ${ }^{20}$ Patent examination refers to the ability of patent examiners to make a correct judgment about whether or not to grant a patent application. This also invariably means that the decisions of patent examiners about the validity and scope of protection are consistent with the patent rules and subsisting court judgements. Rules of examination and judicial pronouncements are usually made after a comprehensive review of the application. ${ }^{21}$ Patent examination, therefore, requires many things: from considerable knowledge and skill in the technological area to knowledge of evolving court rulings. ${ }^{22}$ Nigeria has a depository patent system of patent application, which means that patent applications made at the Nigerian Trademarks, Patents and Designs Registry, are merely examined for compliance with the requisite formalities deemed necessary for the grant of a patent. ${ }^{23}$ This includes consideration as to whether the correct official forms and requisite fees have been paid. However, such an examination is not carried out without recourse to the existing patent rules. ${ }^{24}$

Currently, the examination process of patent applications in Nigeria is not without certain peculiar challenges that require diligent attention. ${ }^{25}$ Some of the challenges include insufficient government funding, lack of basic education and expertise, especially in the various fields of technology, access to historical databases and libraries, lack of sufficient international cooperation with other countries, hence sustaining wasteful duplication of applications, the formation of regional cooperation and databases and effective use of modern information and communication technology, and other deficiencies. ${ }^{26}$

20 WIPO, Alternatives in Patent Search and Examination (WIPO 2014) 4 <https://www.wipo.int/edocs/ pubdocs/en/wipo_pub_guide_patentsearch.pdf> accessed 12 March 2019. The territoriality of the global patent system play a key role in patent examinations. Nations have the option to choose the type of examination they desire.

21 John. L King, 'Patents in the Knowledge-Based Economy', Patent Examination Procedures and Patent Quality (National Academies Press 2003) 4.

22 National Research Council and others, A Patent System for the 21st Century (National Academies Press 2004) 42-46.

23 Patents and Designs Act,s 4.

24 Patent examination in Nigeria is guided by the Patent Rules, LN 96, 1971(subsidiary legislation of the Patent Act).

25 This also includes drafting a patent application, which is a rigorous exercise in technical language that must accommodate the technology underlying the invention, its commercial significance, and relevant statutory and case law.

26 Carlos A Primo Braga and Carsten Fink, 'Reforming Intellectual Property Rights Regimes: Challenges for Developing Countries' (1998) 1 Journal of International Economic Law 547,549. 
Countries of the world are at liberty to use depository or substantive examination systems for granting patents. ${ }^{27}$ In countries with depository systems, patent applicants are simply required to file the correct forms and pay the requisite fees to be granted a patent. In other words, cursory checks are carried out on patent applications to ensure that patentability criteria are met before the granting of patents. Conversely, under standard examination systems, the merits of a patent application are reviewed by expert examiners, and applicants must demonstrate that patentability criteria have been met to receive monopoly protection. ${ }^{28}$ One of the important tasks of a patent office is to decide whether a patent shall be granted, or an application shall be refused, based on the procedures and patentability requirements under the applicable national law. Making such decisions accurately, effectively, and efficiently is a complex mission, involving deliberate policy changes and strong political will. In reality, there is evidence to show that uncertain intellectual property rights impose several kinds of costs on the economy. ${ }^{29}$ It also leads to unnecessary legal disputes to determine the validity or proper scope of a patent when examination quality is lower. Legal costs are especially high when patent disputes result in litigation..$^{30}$ There are available options in finding a way forward. One option is to amend legislation, either to designate the Patent Registry with the sole responsibility of examining patents, or to designate another part of the patent office an authority other than the Patent Registry. This authority could be another authority of the same country, either a scientific institution for instance or an authority located outside the country, in particular, an international preliminary examining authority under the PCT. ${ }^{31}$ Nigeria does not currently conduct any form of examination of patent applications but is now considering the options in this regard. ${ }^{32}$ Thus, having a substantive examination in Nigeria's patent system is advantageous as compared to the absence of it. There has been stiff opposition, especially by multinational pharmaceutical companies, to the intention of many African countries adopting the substantive examination process. ${ }^{33}$ One of the arguments put forward by the opponents was that implementing substantive 27 The Patent Cooperation Treaty (PCT) (as modified on October 3, 2001).

28 Catherine Tomlinson and others, 'Reforming South Africa's Procedures for Granting Patents to Improve Medicine Access' (2015) 105 South African Medical Journal 741.

29 JohnL King, Patents in the Knowledge-Based Economy (2003) $54<$ <htps://www.nap.edu/ read/10770/chapter/4> accessed 5 January 2019. In other words, it provides a strong deterrence against infringement claims.

30 ibid.

31 World Intellectual Property Organization, WIPO Model Law for Developing Countries on Inventions (WIPO 1979) 78. The good news is that Nigeria is PCT compliant. Applications at the Patent Registry pass through an international search procedure for prior art.

32 ibid. Even though no options have been adopted yet in Nigeria, save for recent recommendations by Nigerian Law Reform Commission on amendments to the current PDA.

33 "PCT" refers to the Patent Cooperation Treaty. See Correa (n 4) 7. 
examination will take several years to complete and will be too costly and that the system would also discourage patent applications that may not survive serious substantive analysis. ${ }^{34}$ However, these arguments may be diversions and sabotage against the main advantage of the substantive process of examination, which is to ensure good patent quality.

Registration of patents by patentees in Nigeria is made at the Nigerian Trademarks, Patents and Designs Registry which a registry under the Federal Ministry of Trade and Investment. Applications made at the at Trademarks, Patents and Designs Registry are usually depository in nature. The existing statutory backing for such examination in the PDA is section 4(1) which states:

The Registrar shall examine every patent application as to its conformity with section 3(1), (3) and (4) of this Act, and-(a) if section 3(1) of this Act has not been complied with, the Registrar shall reject the application;(b)if section 3(3) of this Act has not been complied with, the Registrar shall-(i) invite the applicant to restrict the application so that it relates to only one invention, and(ii) notify the applicant that he may within, three months file in respect of the other inventions dealt with in the original application subsidiary applications which shall benefit from the date of filing of the original application and, if relevant, from the date of any foreign priority claimed under section 3(4) of this Act, and, if the applicant does not comply with the invitation mentioned in subparagraph (i) of this subsection, shall reject the application, and(c) if section 3(4) of this Act has not been complied with, the Registrar shall disregard any claim for foreign priority.

Section 4(2)(3)(4) of PDA is explicit about the method of examination in Nigeria. According to Section 4(2):

Where the examination mentioned in subsection (1) of this subsection shows that a patent application satisfies the requirements of section $3(1)$ and (3) of this Act, the patent shall be granted as applied for without further examination and, in particular, without examination of the questions- (a) whether the subject of the application is patentable under section 1 of this Act; (b)whether the description and claims satisfy the requirements of section 3(2) of this Act; and (c) whether a prior application, or an application benefiting from a foreign priority, has been

34 ibid. 
made in Nigeria in respect of the same invention, and whether a patent has been granted as a result of such an application.

Section 4(3) states that

Where the said examination shows that section 3(4) of this Act has been complied with as respects a claim for a foreign priority, the foreign priority claimed shall be mentioned in the patent.

Some developing countries in a similar situation like Nigeria have made attempts to remodel their patent examination methods. Consequently, they created world-class generic drug manufacturing industries by excluding at first and reintroducing process pharmaceutical patents to comply with their obligations as WTO members. These emerging superpower states made such changes while mired in poverty and public health crises. For example, in Indian jurisdiction, the formal and substantive methods of patent examination are practised. ${ }^{35}$ Another country that has recorded a success story on patent examination and a good patent system in Brazil as inventions are subject to formal and substantive examinations before being patented. Today, because of its success story, Brazil issues more patents to foreigners than any other South American country and more patents to foreigners than to Brazilians. ${ }^{36}$ Hitherto, the patent examination systems of the countries cited above were purely depository. Deliberate efforts and mechanisms were put in place by their respective governments to change the type of examination. South Africa, like Nigeria, uses the depository system. ${ }^{37}$ However, it is no longer a secret that its patent office is proposing to implement substantive search and examination (SSE), especially in specific technology sectors ${ }^{38}$ The new IP Consultative Framework, which was approved by Cabinet on $6^{\text {th }}$ July 2016, earmarked 35 Indian Patent Rules ( as amended) 2003, ss 1-16,24-40. Examination of patents in Asian countries like Thailand, Malaysia and Singapore are a substantive, and more rigorous than the depository system in Nigeria.

36 Donald G Daus, 'Patents in Brazil' (1983) 8 North Carolina Law Journal of International Law and Commercial Regulation 1.

37 The South African patent examination System, like that of Nigeria, has shortcomings, such that many patents granted in its current IP system fail to meet the country's patentability criteria. This is as a result of the depository system used for granting patents in the country without examination of their merits. Given the lack of examination in South Africa, many patents are granted are rejected by countries and regions, including Brazil, the USA and the European Union (EU), that have examination systems in place.

38 Robyn-Leigh Merry, 'South Africa:The Intention to Become a Substantive Search and Examination Office' (Mondaq, 18 October 2017) <https://www.mondaq.com/southafrica/patent/638086/the-intention-tobecome-a-substantive-search-and-examination-office> accessed 6 October 2020."plainCitation"."'RobynLeigh Merry, 'South Africa:The Intention to Become a Substantive Search and Examination Office' (Mondaq, 18 October 2017 
the implementation of SSE as an item for immediate domestic review. ${ }^{39}$ Policymakers and law reform specialists have a benchmarked with other jurisdictions, in order to inform a change of policy positions. Thus, the progress of South Africa in the area of organic chemistry, engineering (mining), petroleum, and biodiversity (plants) have suggested that South Africa should incrementally establish examination capability with depositary/ examination systems.

\section{Rethinking the Patent Examination Procedure}

The past few years have seen an increase in the number of patent applications filed in many African countries or with regional organisations. With the increase in patent filings, the debate over the issue of substantive examination has intensified. ${ }^{40}$ Generally, patent examination procedures affect the patent quality and determine the patentability of patent applications. A patent that has been subjected to good examination, at a minimum, describes a newness, inventive step and industrial application covering eligible subject matter in such full and definite terms that others can understand how to make and use it. ${ }^{41}$ Also, the success of any national patent system depends on how well organised its patenting procedures are carried out in its patent office. Good examples of success stories triggered by restructured patent offices are South-East Asian countries like India and Korea. The Korean patent policy and the activities of the Korean Intellectual Property Office (KIPO), for instance, have been integral components in Korea's successful growth

39 Von Seidels, 'South Africa Prepares for a Thorough Examination' (Von Seidels: Intellectual Property Attorneys, 8 March 2017) <http://www.vonseidels.com/south-africa-prepares-for-a-thoroughexamination/> accessed 12 March 2019. Examiners have been appointed by the Patent Office in South Africa to include: No less than 20 trainee patent examiners; Of the 20 trainee examiners, 11 have PhDs, 6 have Master's degrees and 2 have Bachelor Honours degrees; While qualifications are spread out over a number of technical fields, the overwhelming majority are in the life sciences with a strong focus on chemistry, biochemistry and medicinal chemistry; Secondary fields of qualification include electrical and electronic engineering and pure physics; Assuming for the moment that each examiner can examine 2 to 3 new applications every work week of the year, this would imply that 20 examiners could examine roughly 2000 to 3000 new applications in a year. The trainee examiners are undergoing a two-year extensive training programme before they can formally start examining new applications. This realistically pushes out the start of SSE to at least the end of 2018; The trainee examiners have received first-hand training from the Japanese Patent Office, the WIPO and, most notably, the European Patent Office (EPO);The EPO have also been contracted to conduct the bulk of the training over the next two years. SSE in line with EPO practice can therefore be expected, probably rightly so seeing as our patent laws are largely the same patent applications in the pharmaceutical and other chemistry-based fields will be the first to be examined. This is in line with both the Draft Policy and the Consultative Framework.

40 Adams and others, 'Enforcing IP Rights in Africa'(Lexicology, 24 October 2014) <https://www.lexology. com/library/detail.aspx?g=af8c1fbf-aa3b-4079-b1bd-250cffd319aa> accessed 5 January 2019.

41 Christi Guerrini, 'Defining Patent Quality' (2014) 82 Fordham Law Review 3080. 
strategy and continue to be important factors in ensuring Korea's economic wellbeing. ${ }^{42}$ Korea has long been a proponent of strong patent protection and of the need to maintain a robust, well-functioning patent office that supports the development of local technology. That view is consistent with the notion, to which Korea subscribes that the patent system can help promote and sustain healthy economic development, particularly in emergingor newly industrialising-countries. ${ }^{43}$

There are issues with the examination of patents in Nigeria that need reform. First, as pointed out, the Nigerian patent system has a formal system of patent examination where approvals of patents are hinged on merely filing the necessary application form and relevant supporting documents, which are then examined by an examiner to ascertain the patentability of the proposed invention claimed. ${ }^{44}$ The PDA generally acknowledges the examination of the form of patent applications.$^{45}$ However, there are no provisions for examination as to the substance of patent applications, since Nigeria does not have the substantive examination process in its patent legislation. The provisions in the patent rules support only the formal examination process. ${ }^{46}$ The purpose of the application as to form is to ascertain that there are no formal defects other than those that would prevent a filing date from being assigned to the application, while examining applications as to their substance requires an intensive study at the inventive steps taken in acquiring the invention to ascertain its patentability. Section 4(1) of the PDA states that "the Registrar shall examine every patent application as to its conformity with section 3(1), (3) and (4) of this Act." This means that the sole responsibility of examining patent applications lies in the Registrar of patents. Section 4(2) is critical. It states that:

Where the examination mentioned in subsection (1) of this subsection shows that a patent application satisfies the requirements of section $3(1)$ and (3) of this Act, the patent shall be granted as applied for without further examination and, in particular, without examination of the questions...

Section 4(4) is another critical aspect of the PDA. It states that "patents are granted at the risk of the patentee and without guarantee of their validity." This provision then means that the patentee, not the patent office bears the risk of the validity of his or her

42 Jay Erstling, 'Korea's Patent Policy and Its Impact on Economic Development: A Model for Emerging Countries?' (2010) 11 San Diego International Law Journal 443.

43 ibid.

44 Nigeria Patent Rules 1971 ss 1-46. See also Patents and Designs Act, ss 3-6.

45 ss. 3 and 4.

46 Rules 8-43 of the Patent Rules 1971. 
patent application, as the examination procedure cannot fully guarantee such validity. ${ }^{47}$ The procedure is quite different from that of countries like India, Kenya, South Africa, and others that apply both formal and substantive systems of patent examination. The inclusion of the substantive examination procedure into the Nigerian patent system, particularly the patent office, would not just make it a substantive search and examination office but would also complement its existing formal system of examination. Making such a decision accurately, effectively, and efficiently is a complex mission, involving deliberate policy changes and strong political will. In reality, there is evidence to show that uncertain intellectual property rights impose several kinds of costs on the economy. ${ }^{48}$ It also leads to unnecessary legal disputes to determine the validity or proper scope of a patent when examination quality is lower. Legal costs are especially high when patent disputes result in litigation. ${ }^{49}$ There are available options in finding a way forward. One option is modelling patent granting procedures in the Nigerian patent office, such as patent search and examination, in the context of the entire patent system, including the judiciary, which has the ultimate competence to decide on the validity of patents, if they are challenged in court. It should also be considered within limited national resources. In other words, patent search and examination within a patent office should support the broader policy goal of maximising the social gains from the patent system against the social costs for maintaining the patent system. In that regard, a country's allocation of costs among a patent applicant, third parties, a patent office, and a judicial body has to be carefully evaluated, taking into consideration socio-economic development and the way the patent system is utilised in the country. ${ }^{50}$

Another option is to amend legislation. According to some recommendations proferred by WIPO, there is the option of either to designating the Patent Registry with the sole responsibility of examining patents or designating another authority other than the Patent Registry. It recommends that this authority could be another authority of the same country, either a scientific institution, for instance or an authority located outside the country, in particular, an International Preliminary Examining Authority under the PCT. ${ }^{51}$ The alternative set out could be legitimised by special provisions in the Regulations to 47 This procedure is the existing practice, and it is understandable, because the substantive examination system is very expensive and requires a lot of training and equipping of the patent office and its staff. 48 John. L King, Patents in the Knowledge-Based Economy (2003)54 <https://www.nap.edu/ read/10770/chapter/4> accessed 5 January 2019. In other words, it provides a strong deterrence against infringement claims.

49 ibid.

50 WIPO,'Alternatives in Patent Search and Examination' <https://www.wipo.int/edocs/pubdocs/en/ wipo_pub_guide_patentsearch.pdf> accessed 5 January 2019.

51 World Intellectual Property Organization (n 25) 78. The good news is that Nigeria is PCT compliant. Applications at the Patent Registry pass through an international search procedure for prior art. 
designate the searching and examining authority. The recommendations go further to state that the legislation should also put in place the details of the relations between the Patent Office and the authority and to lay down the procedure before the authority; the relations and procedure referred to may also be set out in a working agreement between the Patent Office and the authority. ${ }^{52}$ Under the alternative, the task of the authority is not limited to searching. However, such a limitation could be provided for, in which case the Patent Office would carry out the actual examination itself. The Patent Office should also have the power to alter the conclusions in the authority's report if they are not in conformity with the national law.

Finally, the Nigerian Patent Registry can learn from the experience of India by providing a manual or guideline of patent practice and procedure. ${ }^{53}$ The use of a manual or guideline is quite laudable. Judicial decisions on procedural matters should also be included in the manual. The manual should not supplement the existing Patent Rules. The manual should solely be intended to codify the practices and procedures being followed by the Nigerian Patent Registry and also designed to serve as a procedural guide for the practitioners and other users of the Nigeria Patent System.

\section{Patent Administration Reforms}

Customarily, the Nigerian patent system, like other patent systems, is not made up of only the national patent office, i.e., the Trademarks, Patents and Designs Registry at the Federal Ministry of Trade and Investment. ${ }^{54}$ It synergises with some establishments of government, each playing a role, to make the patent system sustainable. Thus, patent inventions cannot be possible without giving a high priority to patent office administration. The need to focus on the role of the national patent office cannot be overemphasised. It administers patent standards that are decided and defined by the courts, legislatures, or the executive actions in the context of treaty negotiation. ${ }^{55}$

A good national patent system is seen not only in the existence of a patent office but also a competent and result-oriented administration for patent rights protection. It is also seen in its ability and competence in enforcing patent legislation with competence and diligence, thereby gaining the trust of local and international patentees. Such attributes

52 ibid.

53 Indian Patent Office, 'Manual of Patent Office Practice and Procedure'<https://wipolex.wipo.int/en/ text/201589> accessed 21 February 2019.

54 Ruth Taplin and Alojzy Z Nowak, Intellectual Property, Innovation and Management in Emerging Economies (Routledge 2010) 51-54.

55 Peter Drahos, 'Trust Me: Patent Offices in Developing Countries' (2008) 34 American Journal of Law \& Medicine 151, 2. 
have the propensity for improving the quality and quantity of patents, and also boosting the transfer of technology through registration of patented protected by foreign firms. Another endeavour that can foster the growth and progress of the patent office is reducing the cost of registration by engaging in bilateral agreements for foreign technical support or MOUs to unify administrative practices. ${ }^{56}$ These are some of the missing ingredients in the Nigerian patent system.

Another issue to be confronted by the Nigerian Patent office, like any other patent office in a developing country, is its behaviour towards local patentees and local inventions as it is steadily integrated into an emerging system of global patent administration. ${ }^{57} \mathrm{By}$ this integration, it is disposed to behave in ways that are likely to be pro-foreign patent. Thus, if care is not taken, through its daily administrative practices, the patent offices will increasingly help to maintain foreign patent-regulated markets that will increase the difficulties surrounding the access of Nigerians to foods, medicines, and other goods. This raises the issue of how the Nigerian patent office should respond to functions in the Patent Registry.

There are many problems associated with patent office administration in Nigerian Patent Registry. Some of these problems have been identified to include the lack of uniform and consistent practice, and lack of adequate human resources, the lack of an efficient and well-regulated system to dispense the patents for inventions. These bureaucratic delays have caused organisational problems, neglect by the government despite constant appeals for more money, more clerks, and better organisation, and other issues. Some countries have overcome many of their patent administration challenges. The Nigerian Patent Registry can implement some reforms from the experiences of other countries. One of the first reforms is improvising ways of disseminating knowledge to Nigerians about what it does. Knowledge in this sense would include knowing about its operations, including its relations with pharmaceutical and other companies, their relationships with other patent offices, and the quality of their examination systems. This is the first step if the country wants to integrate their patent offices into its national economic strategy. Another good reform could be adopting the model of patent office regulation in the area of pharmaceuticals that operates by prevention. This has been practised in Brazil since 1999

56 ibid 3. For example, There are existing bilateral and trilateral patent offices between the USPTO , the EPO and the JPO which have moved well beyond simple technical co-operation into a much deeper convergence of administrative systems. Some developing countries are being integrated into the Trilateral system of governance for patent administration, like in the case of France and some West African Francophone countries.

57 Peter Drahos, The Global Governance of Knowledge: Patent Offices and Their Clients (Cambridge University Press 2010) 177-199. 
when it passed a measure that made the grant of patents on pharmaceutical products and processes dependent on the consent of the Brazilian Sanitary Surveillance Agency (ANVISA) ${ }^{58}$ Brazil's intellectual property office processes patent applications concerning pharmaceuticals in the normal way, but ANVISA scrutinises them for compliance with the requirements of patentability.

Another policy for consideration is that the Nigerian Patent Registry can establish patent transparency registers in areas of technology where there are risk-management severe issues and where transparency concerning the patent situation is necessary. ${ }^{59}$ This innovation would fulfil the TRIPs obligations of protecting human, animal or plant life or health or avoid serious prejudice to the environment under Article 27(1)(a) of TRIPs. ${ }^{60}$ The scope of the transparency register's operation should be for the patent office or an assigned regulator to decide as part of a risk-assessment exercise. The use of registers 58 David M Trubek and others, Law and the New Developmental State: The Brazilian Experience in Latin American Context (Cambridge University Press 2013) 217.emerging forms of state activism, including a new industrial policy and a robust social policy, differ from both classic developmental state and neoliberal approaches. They favor a strong state and a strong market, employ public-private partnerships, seek to reduce inequality, and embrace the global economy. Case studies of state activism and law in Brazil show new roles emerging for legal institutions. They describe how the national development bank uses law in innovation promotion, trade law strengthens new developmental policies in export promotion and public health, and social law frames innovative poverty-relief programs that reduce inequality and stimulate demand. Contrasting Brazilian experience with Colombia and Mexico, the book underscores the unique features of Brazil's trajectory and the importance of this experience for understanding the role of law in development today.,"'ISBN":"978-1-107-35538-5","language":"en","note":"'Google-Books-ID: 2ysgAwAAQBAJ","number-of-pages":"393","publisher":"Cambridge University Press","source":"'Google Books","title":"Law and the New Developmental State: The Brazilian Experience in Latin American Context","title-short":"'Law and the New Developmental State","author":[["family":"Trubek","'given":"'David M."\},\{“family":"'Garcia","given":"Helena Alviar"\},\{ffamily":"Coutinho","given":"'Diogo R."\},\{"family":"'Santo

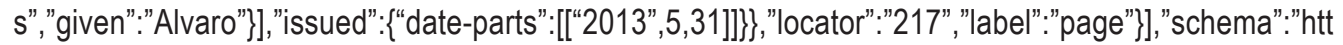
ps://github.com/citation-style-language/schema/raw/master/csl-citation.json"\} As a matter of practice, if Brazilian ANVISA concludes that the patent application fails to meet one or more of the criteria of patentability, it can withhold its consent to the grant of the patent in which case the patent cannot issue. The Brazilian model is worth close study by other developing countries. It is a preventive strategy that avoids the high costs of attempting to remove patents that have been granted. It is also an integrative regulatory strategy. It links patentability criteria in the area of pharmaceuticals to the goal of welfareenhancing innovation in the health sector.

59 Paul Grootendorst, Ron Bouchard and Aidan Hollis, 'Canada's Laws on Pharmaceutical Intellectual Property: The Case for Fundamental Reform' (2012) 184 CMAJ : Canadian Medical Association Journal 543. Transparency registers would only need to be created by regulatory agencies in areas where it was important to reduce the social costs of the uncertainty and complexity being orchestrated by patent owners.

60 Young-Gyoo Shim, 'Intellectual Property Protection of Biotechnology and Sustainable Development in International Law' 29 North Carolina Law Journal of International Law and Commercial Regulation 166. 
would not, in other words, be confined to a particular type of technology. Companies would be required to use the registers to make full disclosure of the patents surrounding the targeted technology. Other companies would be able to rely on the register, knowing that surprise would not be sprung on them. Also, the registers would require the disclosure of information relating to ownership and license. This information is, in practice, challenging to track down. However, the cost to a company of not disclosing a patent on a transparency register that it should have disclosed could be some form of estoppel that would prevent it from enforcing that patent. ${ }^{61}$ This would compel disclosure by some firms which might respond by flooding the transparency register with patents.

Reforms such as the few mentioned above have the potential to address the issues encountered in Nigerian patent office administration. In studying and finding solutions for proper patent office administration, fundamental questions need to be addressed. Basic questions like: how did the office function during this time of neglect? Why was it neglected? What is prompting the necessary reforms? ${ }^{62}$ The answer lies in a combination of formulating and adopting national strategies and policies which consider public interest, and also a result-oriented implementation of such policies.

\section{Conclusion}

The discourse so far looked at patent legislation and the process of examination of patents in Nigeria. It affirms that the examination process of patents in Nigeria is a depository process and not substantive as practised in some jurisdictions. Rethinking the Nigerian patent examination system and the need for reforms in the patent administration are also discussed as aspects of the Nigerian patent system that require reform. The significance of examination of patent applications cannot be overemphasised, as it serves as the administrative procedure for an examiner to deliberate the formality and content of the registration application and decide whether or not to register it. Understandably, the article acknowledges that the substantive process of examination of patents is expensive and cumbersome. However, it is suggested that a shift towards the substantive process of examination would not only ensure a good quality of patents but also aide of the Nigerian patent system towards attaining technological and economic development. In achieving this, certain steps need to be taken, and specific changes need to be made. These include massive funding, training of experts in different fields of substantive examination, creating the right environment for patents to thrive, among other reforms. 61 For example, s 26(c) of the Therapeutic Goods Act 1989 of Australia imposes a penalty of 10 million Australian dollars to deter companies from using patents of doubfful validity as part of a strategy of preventing or delaying the registration of generic drugs. Much higher fines than these are needed, as well as criminal penalties.

62 Daniel Preston, 'The Administration and Reform of the U. S. Patent Office, 1790-1836' (1985) 5 Journal of the Early Republic 331, 332. 
Above all, the most significant reform is the need for Nigeria to evolve a political culture that prioritises IP as an indispensable means for economic development. Thus, national development plans should accord high priority to IP protection, especially the protection of patent rights. 


\section{References}

Abdulai Taiwo and Co, 'Requirements and Procedure for Patent Registration in Nigeria' (Lexicology, 6 February 2019) <https://www.lexology.com/library/detail. aspx?g=f0321f8b-0da4-4480-b424-ca31ca894726> accessed 6 October 2020

Adams and others, 'Enforcing IP Rights in Africa' (Lexocology, 24 October 2014) $<$ https://www.lexology.com/library/detail.aspx?g=af8c1fbf-aa3b-4079-b1bd250cffd319aa> accessed 5 January 2019

Chandran Govindaraju VGR and Wong C-Y, 'Patenting Activities by Developing Countries: The Case of Malaysia' (2011) 33 World Patent Information 51

Collin PH, Dictionary of Law, Bloomsbury Reference Book, 2004: Dictionary of Law (Bukupedia 2004)

Correa CM, 'Patent Examination and Legal Fictions: How Rights Are Created on Feet of Clay' in Peter Drahos, Gustavo Ghidini and Hanns Ullrich, Kritika: Essays on Intellectual Property (Edward Elgar Publishing 2015)

Correa CM, 'Intellectual Property: How Much Room Is Left for Industrial Policy?' (2016) 07 Journal of International Commerce, Economics and Policy 1650012

Council NR and others, A Patent System for the 21st Century (National Academies Press 2004)

Daus DG, 'Patents in Brazil' (1983) 8 North Carolina Law Journal of International Law and Commercial Regulation

Drahos P, 'Trust Me: Patent Offices in Developing Countries' (2008) 34 American Journal of Law \& Medicine 151

Drahos P, The Global Governance of Knowledge: Patent Offices and Their Clients (Cambridge University Press 2010)

Dreyfuss RC and Pila J, The Oxford Handbook of Intellectual Property Law (Oxford University Press 2018)

Erstling J, 'Korea's Patent Policy and Its Impact on Economic Development: A Model 
for Emerging Countries?' (2010) 11 San Diego International Law Journal

Grootendorst P, Bouchard R and Hollis A, 'Canada's Laws on Pharmaceutical Intellectual Property: The Case for Fundamental Reform' (2012) 184 CMAJ :

Canadian Medical Association Journal 543

Guerrini C, 'Defining Patent Quality' (2014) 82 Fordham Law Review

Hornby AS and Cowie AP, Oxford Advanced Learner's Dictionary of Current English (7th edn, Oxford Univ Pr 2005)

Indian Patent Office, 'Manual of Patent Office Practice and Procedure' <https://wipolex. wipo.int/en/text/201589> accessed 21 February 2019

King John L, Patents in the Knowledge-Based Economy (2003) <https://www.nap.edu/ read/10770/chapter/4> accessed 5 January 2019

King John L, 'Patents in the Knowledge-Based Economy', Patent Examination

Procedures and Patent Quality (National Academies Press 2003)

Martin EA, A Dictionary of Law (5th edn, Oxford University Press 2009)

Merry R-L, 'South Africa:The Intention to Become a Substantive Search and Examination Office' (Mondaq, 18 October 2017) <https://www.mondaq.com/ southafrica/patent/638086/the-intention-to-become-a-substantive-search-andexamination-office> accessed 6 October 2020

Okediji RL and Bagley MA, Patent Law in Global Perspective (Oxford University Press 2014)

Olubanwo F and Oguntuase O, 'Strengthening Intellectual Property Rights and Protection In Nigeria' (Mondaq, 11 March 2019) < https://www.mondaq.com/ nigeria/trademark/788714/strengthening-intellectual-property-rights-andprotection-in-nigeria> accessed 27 May 2020

Preston D, 'The Administration and Reform of the U. S. Patent Office, 1790-1836' (1985) 5 Journal of the Early Republic 331 
Primo Braga CA and Fink C, 'Reforming Intellectual Property Rights Regimes: Challenges for Developing Countries' (1998) 1 Journal of International Economic Law

Shim Y-G, 'Intellectual Property Protection of Biotechnology and Sustainable Development in International Law' 29 North Carolina Law Journal of International Law and Commercial Regulation

Taplin R and Nowak AZ, Intellectual Property, Innovation and Management in Emerging Economies (Routledge 2010)

Tomlinson $\mathrm{C}$ and others, 'Reforming South Africa's Procedures for Granting Patents to Improve Medicine Access' (2015) 105 South African Medical Journal 741

Trubek DM and others, Law and the New Developmental State: The Brazilian Experience in Latin American Context (Cambridge University Press 2013)

Vanni A, Patent Games in the Global South: Pharmaceutical Patent Law-Making in Brazil, India and Nigeria (Bloomsbury Publishing 2020)

Von Seidels, 'South Africa Prepares for a Thorough Examination' (Von Seidels: Intellectual Property Attorneys, 8 March 2017) <http://www.vonseidels.com/southafrica-prepares-for-a-thorough-examination/> accessed 12 March 2019

WIPO, Alternatives in Patent Search and Examination (WIPO 2014) <https://www.wipo. int/edocs/pubdocs/en/wipo_pub_guide_patentsearch.pdf> accessed 12 March 2019

WIPO, 'Alternatives in Patent Search and Examination' <https://www.wipo.int/edocs/ pubdocs/en/wipo_pub_guide_patentsearch.pdf> accessed 5 January 2019

World Intellectual Property Organization, WIPO Model Law for Developing Countries on Inventions (WIPO 1979)

Yankey GS-A, International Patents and Technology Transfer to Less Developed Countries: The Case of Ghana and Nigeria (Avebury 1987) 


\section{UCC FACULTY OF LAW JOURNAL GUIDELINES FOR CONTRIBUTORS}

\section{Submission}

The Journal invites submissions from around the world in interdisciplinary, methodological, and theoretical perspectives of the law. The subject fields include Law and Legal History/philosophy, African History /Studies, Criminology and Criminal Justice, Women's and Gender History/Studies, Teaching and Learning, Political Science, and other socio-legal studies. Prior to submission, prospective contributors are welcome to discuss ideas for their work proposal. The journal is a double-blind review. Manuscript for Articles of sufficient standard will be read independently by editors and at least two reviewers. Name of authors will be anonymous.

All submissions should be sent to the editors in DOC format or via the Journal online platform.

Word limits for manuscript vary according to the section and nature of the subject of work. The following therefore serves only as a guidance. All word counts are inclusive of footnotes.

Articles --- 6,500-12,500

Notes --- 5,000-8,000

Case Reviews ---- 1,500-2,500

Book Reviews ---- 500-1,500

Articles should also accompany with an abstract of no more than 250 words.

\section{House Style}

All manuscript must be written in English and conform to the Oxford Standard Citation of Legal Authorities (OSCOLA).

The manuscript must also be submitted in standard A4 format in 12 point, Times New Roman with double-spacing in the text body, and in 10 point, Times New Roman with single-spacing in the footnotes and quotations.

Title should be centred. Name of the author should also be centred, and in title case, and small-caps. 


\section{Proof}

Authors will be sent page proofs by email. They should check the same thoroughly, return any corrections or revisions and reply with any questions to the editors. Further details will accompany the proof. 